\title{
Persepsi Pasien DM Tipe 2 Terhadap Penggunaan Obat Antidiabetes Oral di RSUP Dr. Hasan Sadikin Bandung
}

\author{
Perception Type 2 DM Patients about the Use of Oral Antidiabetic Drug in Dr. Hasan Sadikin General \\ Hospital Bandung
}

\author{
Eko Kuncoro Manunggaling Gusti ${ }^{1^{*}}$, Kuswinarti ${ }^{2}$, Anisah Dahlan ${ }^{3}$ \\ 1. Program Studi Kedokteran, Fakultas Kedokteran, Universitas Padjadjaran, Bandung \\ 2. Divisi Farmakologi dan Terapi, Departemen Ilmu Kedokteran Dasar, Fakultas Kedokteran, Universitas Padjadjaran, \\ Bandung \\ 3. Divisi Biokimia dan Biologi Molekuler, Departemen Ilmu Kedokteran Dasar, Fakultas Kedokteran, Universitas \\ Padjadjaran, Bandung \\ Submitted: 25-11-2019 \\ Revised: 18-03-2020 \\ Accepted: $20-03-2020$ \\ Korespondensi : Eko Kuncoro Manunggaling Gusti : Email : ekokuncoro98@gmail.com
}

\section{ABSTRAK}

Diabetes melitus tipe 2 (DMT2) merupakan penyakit metabolik seumur hidup yang ditandai oleh kondisi hiperglikemia, sehingga memerlukan terapi yang terus menerus. Obat Antidiabetes Oral (OAD) menjadi lini utama dalam terapi DMT2. Terdapat beberapa faktor yang memengaruhi kepatuhan dan konsumsi obat, salah satunya adalah persepsi. Persepsi merupakan proses pengolahan informasi sensoris hingga membentuk suatu makna yang akan membuat seorang pasien DMT2 mengambil keputusan untuk mengonsumsi obat secara teratur dan berkelanjutan. Tujuan penelitian ini adalah mengetahui persepsi pasien DMT2 terhadap penggunaan OAD di Poliklinik Endokrin RSUP Dr. Hasan Sadikin Bandung. Penelitian ini menggunakan metode deskriptif kategorik dengan desain potong lintang. Pengambilan data menggunakan kuesioner yang telah melalui proses uji validitas dan uji reliabilitas. Pengambilan sampel dilakukan dengan metode convenience sampling kepada 46 responden. Variabel yang diteliti pada penelitian ini berupa data karakteristik responden dan persepsi yang dikelompokkan menjadi empat kategori. Data diolah menggunakan Rasch Model menjadi persepsi positif dan negatif berdasarkan nilai mean logit responden. Hasil penelitian menunjukkan, persepsi positif manfaat pengobatan sebesar $73,9 \%$, persepsi positif tata cara konsumsi obat sebesar $78,3 \%$, persepsi positif efek samping pengobatan sebesar $82,6 \%$, dan persepsi positif dorongan konsumsi obat sebesar $67,4 \%$. Secara keseluruhan, persepsi pasien DMT2 terhadap penggunaan OAD di RSHS merupakan persepsi yang positif. Hal ini merupakan landasan yang baik bagi pasien untuk melakukan terapi secara teratur dan berkelanjutan.

Kata kunci: Diabetes Melitus Tipe 2 (DMT2); Obat Antidiabetes Oral (OAD); Persepsi

\begin{abstract}
Type 2 Diabetes Mellitus (T2DM) is a lifelong metabolic disorder characterized by hyperglycemia, which requires continuous therapy. Oral antidiabetic drugs (OAD) become the main line in T2DM therapy. There are several factors influencing drug compliance and consumption, one of them is perception. Perception is a process of processing sensory information to form a meaning that will make T2DM patient take a decision to take the medication regularly and continously. The purpose of the study is to determine the perception of T2DM patients about the use of OAD in the Endocrine Polyclinic, Dr. Hasan Sadikin General Hospital, Bandung. This study uses categorical descriptive method with cross-sectional design. Data is collected using a questionnaire that has been through the process of validity and reliability tests. Sampling was done by convenience sampling method to 46 respondents. The variables in this study are respondents' characteristics and perceptions, which is grouped into four categories. The data was processed using the Rasch Model to be categorized into positive and negative perceptions based on the mean logit respondent value. The results showed positive perception of treatment benefits is $73.91 \%$, positive perception of drug consumption procedures is $78.26 \%$, positive perception of treatment side effects is $82.61 \%$, and positive perception of drug consumption encouragement is $67.39 \%$. Overall, the perception of T2DM patients about the use of OAD in RSHS is a positive perception. This is a good foundation for patients for doing the therapy regularly and continuously. Keywords: Oral Antidiabetic Drug (OAD); Perception; Type 2 Diabetes Mellitus (T2DM)
\end{abstract}




\section{PENDAHULUAN}

Diabetes Melitus (DM) merupakan penyakit gangguan metabolik yang ditandai dengan keadaan hiperglikemia yang disebabkan oleh gangguan fisiologis hormon insulin dalam memasukkan glukosa ke dalam jaringan, gangguan produksi hormon insulin, atau keduanya. Penyakit ini, jika tidak dikontrol, dapat menimbulkan komplikasi multiorgan, seperti neuropati, penyakit ginjal kronis, retikulopati diabetikum, ulkus kaki, dan penyakit pembuluh darah tepi. ${ }^{1,2}$ International Diabetes Federation (IDF) memperkirakan bahwa terdapat 10,3 juta penduduk Indonesia mengalami DM pada tahun 2015 dan diperkirakan terus meningkat hingga mencapai 16,7 juta orang pada 2045 . $^{3}$

DM tipe 2 (DMT2) merupakan jenis DM terbanyak dengan presentase sebesar $90-95 \% .{ }^{4}$ DMT2 merupakan penyakit seumur hidup yang tidak dapat disembuhkan, hanya dapat dikontrol agar tidak semakin memburuk. Strategi penanganan penyakit ini adalah pola gizi seimbang, aktivitas fisik, dan terapi medikasi. Rekomendasi terbaru menyarankan inisiasi peresepan metformin setelah pasien terdiagnosis DMT2. ${ }^{2}$ Menurut RISKESDAS 2018, 75\% pasien DM mendapatkan terapi obat antidiabetes oral (OAD) dari dokter. ${ }^{5}$ Artinya, OAD menjadi lini utama penanganan penyakit DMT2. Namun, kepatuhan minum obat masih menjadi tantangan dalam hal tersebut. Fakta bahwa pasien harus mengonsumsi obat secara teratur setiap hari sering kali menjadi hambatan. ${ }^{2}$

Terdapat beberapa faktor yang memengaruhi kepatuhan penggunaan OAD. Polonsky dan Henry ${ }^{6}$ mengemukakan bahwa terdapat faktor-faktor yang memengaruhi kepatuhan pasien DMT2 dalam konsumsi OAD, seperti persepsi manfaat, efek samping hipoglikemia, kompleksitas tata cara terapi, biaya, kepercayaan terhadap terapi, dan kepercayaan terhadap tenaga medis. Psarou et al.,7 pun mengungkapkan terdapat berbagai faktor yang memengaruhi perilaku minum OAD, seperti persepsi pasien terhadap DM dan pengobatannya, ekspektasi terhadap pengobatan, pengalaman, dan pengetahuan.
Faktor persepsi menjadi kesamaan dalam kedua penelitian tersebut.

Persepsi merupakan proses penyusunan dan penerjemahan informasi sensoris menjadi suatu makna bagi seseorang. Persepsi terjadi melalui perpaduan antara informasi yang ditangkap oleh organ sensoris dengan kemampuan otak untuk mengolah dan memaknainya. Persepsi akan mendorong seseorang untuk melakukan tindakan. ${ }^{8}$ Atas dasar tersebut, persepsi pasien DMT2 terhadap pengobatan OAD menjadi suatu kunci dalam perilaku meminum obat secara teratur dan berkelanjutan. Perlu dilakukan penelitian yang menggambarkan persepsi pasien mengenai pengobatannya untuk menjadi masukan bagi tenaga medis dalam pemberian terapi serta pembentukan persepsi yang baik mengenai OAD yang diresepkan kepada pasien DMT2. Belum ada penelitian di Indonesia yang berfokus pada hal tersebut.

Tujuan penelitian ini adalah mengetahui persepsi pasien DMT2 terhadap penggunaan OAD di Rumah Sakit Dr. Hasan Sadikin (RSHS) Bandung yang merupakan FKRTL tingkat ketiga dan rumah sakit pusat Jawa Barat.

\section{METODE}

Penelitian ini menggunakan metode deskriptif kategorik dengan desain penelitian potong lintang. Penelitian dilakukan dari bulan September sampai November 2019, melibatkan responden pasien rawat jalan Poliklinik Endokrin RSHS dengan kriteria berupa pasien DMT2 yang sedang dalam pengobatan dengan menggunakan OAD sesuai dengan Formularium Nasional, berusia lebih dari 15 tahun, dan bersedia menjadi responden penelitian dengan menandatangani lembar informed consent. Penentuan jumlah sampel dihitung menggunakan rumus sampel deskriptif kategorik yang menghasilkan nilai 46 responden. Pengambilan data menggunakan metode convenience sampling dengan cara menanyakan setiap butir pertanyaan kuesioner kepada responden yang selanjutnya diisikan ke lembar jawaban oleh peneliti. 
Penelitian telah mendapatkan pembebasan etik dari Komite Etik Penelitian Universitas Padjajaran dengan nomor 916/UN6.KEP/EC/2019 dan izin penelitian dari Komite Etik dan Penelitian RSHS dengan nomor LB.02.01/X.2.2.1/1634/2019.

Penelitian ini menggunakan kuesioner yang dibuat sendiri oleh peneliti dan dikonsultasikan kepada ahli. Kuesioner telah melalui proses uji validitas dan uji reliabilitas dengan perangkat lunak Microsoft Excel 2016. Pertanyaan dinyatakan valid apabila nilai koefisien korelasi lebih dari 0,3. Pertanyaan yang tidak valid kemudian dikeluarkan dari kuesioner. Uji reliabilitas kuesioner menggunakan rumus Split-Half Technique yang menghasilkan koefisien reliabilitas sebesar 0,73. Nilai ini masuk kategori reliabilitas tinggi.

Variabel penelitian ini berupa data karakteristik responden dan persepsi yang dikategorikan menjadi persepsi manfaat pengobatan, persepsi tata cara konsumsi obat, persepsi efek samping pengobatan, dan persepsi dorongan konsumsi obat. Data persepsi diolah menggunakan Rasch Model dengan perangkat lunak Winstep 4.4.6 untuk melihat nilai logit tiap responden yang disajikan dalam bentuk Wright Map. Data dikategorikan menjadi persepsi positif dan negatif. Kriteria responden dikatakan memiliki persepsi positif jika nilai logit responden lebih dari sama dengan nilai mean logit responden (ditandai oleh huruf $\mathrm{M}$ ) pada Wright Map. Nilai $\mathrm{M}$ tersebut didapatkan dengan merata-ratakan nilai logit data responden non-extreme.

\section{HASIL DAN PEMBAHASAN}

Penelitian ini melibatkan 46 responden yang memenuhi kriteria. Hasil penelitian berupa data karakteristik responden, empat kategori persepsi, dan distribusi jawaban responden.

\section{Karakteristik Responden}

Data karakteristik responden meliputi jenis kelamin, usia, Pendidikan terakhir, jumlah OAD yang dikonsumsi, hasil pemeriksaan GDP terakhir, hasil pemeriksaan G2PP terakhir, dan hasil pemeriksaan $\mathrm{HbA1c}$ terakhir. Gambaran karakteristik responden disajikan dalam bentuk tabel distribusi frekuensi pada tabel I.

Lebih dari setengah pasien DMT2 di Poliklinik Endokrin RSHS berjenis kelamin perempuan dengan jumlah 25 orang (54,3\%). Responden paling banyak berusia 55-64 tahun dengan jumlah 15 orang $(31,6 \%)$. Berdasarkan pendidikan terakhir, perguruan tinggi memiliki persentase tertinggi yaitu 34,8\% (16 orang). Berdasarkan jumlah OAD yang dikonsumsi, mayoritas responden mendapatkan terapi tunggal sebanyak 24 orang $(52,2 \%)$ dan kombinasi 2 jenis sebanyak 20 orang $(43,5 \%)$. Hasil pemeriksaan glukosa darah puasa terakhir responden didominasi oleh kategori $\geq 126 \mathrm{mg} / \mathrm{dL}$ dengan jumlah 31 orang $(67,4 \%)$. Hasil pemeriksaan glukosa darah 2-jam PP terakhir menunjukkan bahwa 24 orang termasuk kategori $\geq 200 \mathrm{mg} / \mathrm{dL}$ (52,2\%). Pada pemeriksaan HbA1c, tidak semua pasien memiliki atau mengetahui hasil pemeriksaan $\mathrm{HbA1c}$, hanya 13 responden yang mengetahui hasil tersebut. Dari 13 orang, kategori 7,5-9\% dan kategori $>9 \%$ sama-sama memiliki jumlah 5 orang $(38,5 \%)$.

\section{Persepsi}

Persepsi manfaat pengobatan memiliki nilai mean logit (M) sebesar 0,68 (Gambar 1). Berdasarkan nilai tersebut, terdapat 34 responden $(73,9 \%)$ memiliki persepsi positif dan 12 responden $(26,1 \%)$ memiliki persepsi negatif. Persepsi positif manfaat pengobatan berarti pasien mengetahui dan merasakan manfaat dari terapi yang diberikan. Hal tersebut dapat menjadi motivasi pasien dalam mengonsumsi obat secara teratur dan mengontrol kondisi DMT2 pasien. ${ }^{9}$

Persepsi manfaat pengobatan dinilai melalui 4 butir pertanyaan yang tercantum pada tabel II. Mayoritas responden memersepsikan seluruh pertanyaan dengan positif, sejalan dengan penelitian sebelumnya mengenai manfaat pengobatan DMT2. ${ }^{10}$ 
Eko Kuncoro Manunggaling Gusti, et al

Tabel I. Karakteristik Responden

\begin{tabular}{|c|c|c|}
\hline Variabel & Jumlah (N=46) & Persentase $(\%)$ \\
\hline \multicolumn{3}{|l|}{ Jenis Kelamin } \\
\hline Laki-laki & 21 & 45,7 \\
\hline Perempuan & 25 & 54,3 \\
\hline \multicolumn{3}{|l|}{ Usia (tahun) } \\
\hline$<35$ & 1 & 2,2 \\
\hline $35-44$ & 9 & 19,6 \\
\hline $45-54$ & 11 & 23,9 \\
\hline $55-64$ & 15 & 32,6 \\
\hline $55-74$ & 10 & 21,7 \\
\hline$\geq 75$ & 0 & 0 \\
\hline \multicolumn{3}{|l|}{ Pendidikan Terakhir } \\
\hline Tidak Sekolah & 0 & 0 \\
\hline SD & 11 & 23,9 \\
\hline SMP & 7 & 15,2 \\
\hline SMA/SMK & 12 & 26,1 \\
\hline Perguruan Tinggi & 16 & 34,8 \\
\hline \multicolumn{3}{|c|}{ Jumlah OAD yang Dikonsumsi } \\
\hline Tunggal & 24 & 52,2 \\
\hline Kombinasi 2 jenis & 20 & 43,5 \\
\hline Kombinasi 3 jenis & 2 & 4,3 \\
\hline \multicolumn{3}{|c|}{ Glukosa Darah Puasa Terakhir } \\
\hline$<100 \mathrm{mg} / \mathrm{dL}$ & 5 & 10,9 \\
\hline $100-125 \mathrm{mg} / \mathrm{dL}$ & 10 & 21,7 \\
\hline$\geq 126 \mathrm{mg} / \mathrm{dL}$ & 31 & 67,4 \\
\hline \multicolumn{3}{|c|}{ Glukosa Darah 2-Jam PP Terakhir } \\
\hline$<140 \mathrm{mg} / \mathrm{dL}$ & 7 & 15,2 \\
\hline $140-199 \mathrm{mg} / \mathrm{dL}$ & 15 & 32,6 \\
\hline$\geq 200 \mathrm{mg} / \mathrm{dL}$ & 24 & 52,2 \\
\hline HbA1C & ${ }^{*} \mathrm{~N}=13$ & \\
\hline$<7,5 \%$ & 3 & 23,0 \\
\hline $7,5-9 \%$ & 5 & 38,5 \\
\hline$>9 \%$ & 5 & 38,5 \\
\hline
\end{tabular}

Menurunkan kadar glukosa darah merupakan pertanyaan yang paling banyak dipersepsikan positif. Mengurangi atau menghilangkan gejala DM merupakan yang paling sedikit. Setelah didalami lebih lanjut, beberapa responden tidak mengalami gejala apapun. Hal ini terjadi karena DMT2 dapat berupa penyakit yang asimptomatik. Pasien didiagnosis mengalami DM ketika pemeriksaan rutin glukosa darah ataupun setelah terjadi komplikasi. ${ }^{2}$

Persepsi tata cara pengobatan memiliki nilai mean logit $(\mathrm{M})$ sebesar 1,35 (Gambar 2).
Berdasarkan nilai tersebut, terdapat 36 responden $(78,3 \%)$ memiliki persepsi positif dan 10 responden $(21,7 \%)$ memiliki persepsi negatif. Persepsi positif pada tata cara pengobatan berarti pasien mengerti dan dapat menjalankan pengobatan dengan baik.

Persepsi tata cara pengobatan dinilai menggunakan 7 butir pertanyaan yang tercantum pada tabel II. Seluruh pertanyaan dipersepsikan dengan baik oleh lebih dari $70 \%$ responden. Pertanyaan yang paling banyak dipersepsikan negatif oleh responden adalah dapat mengurangi atau menghentikan 
Persepsi Pasien DM Tipe 2 Terhadap Penggunaan Obat Antidiabetes Oral

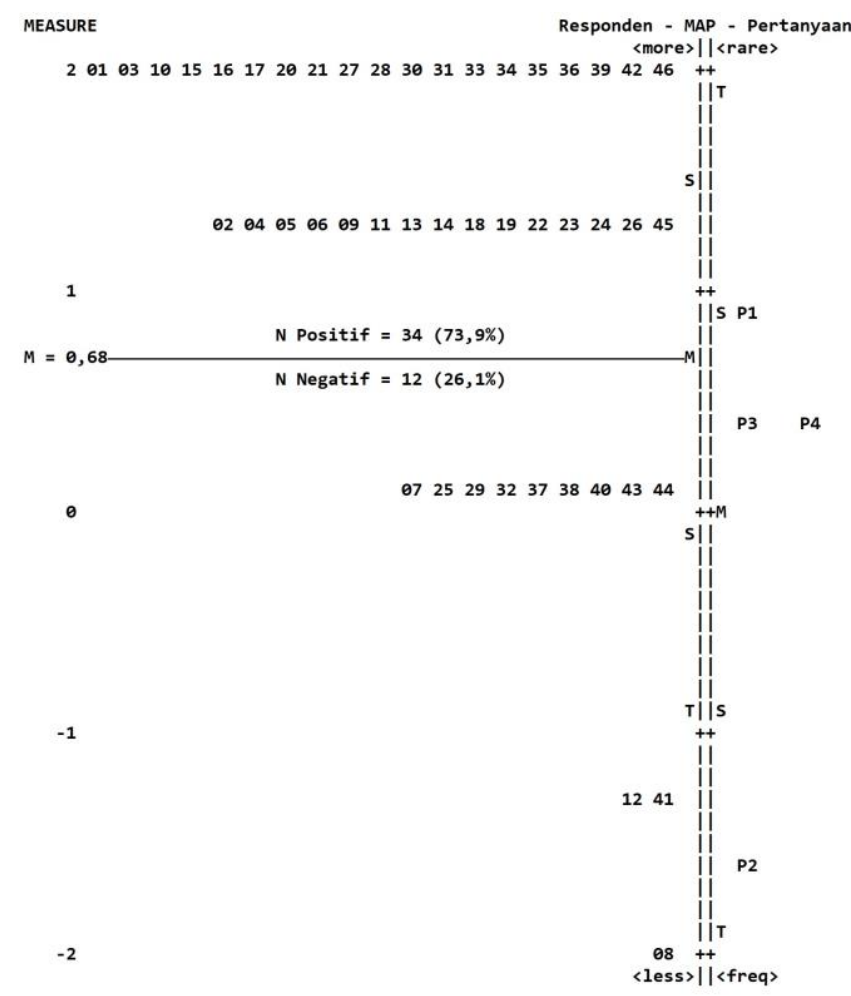

\section{Gambar 1. Wright Map Distribusi Responden dan Item Pertanyaan Persepsi Manfaat Pengobatan}

pemakaian OAD jika sudah merasa lebih baik. Hal tersebut menggambarkan bahwa beberapa responden merasa pengobatan DMT2 bersifat sementara dan DMT2 dapat disembuhkan. Hal ini bertentangan dengan teori bahwa DMT2 merupakan penyakit seumur hidup yang perlu terapi

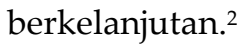

Persepsi efek samping pengobatan memiliki nilai mean logit (M) sebesar 1,05 (Gambar 3). Berdasarkan nilai tersebut, terdapat 38 responden $(82,6 \%)$ memiliki persepsi positif dan 8 responden $(17,4 \%)$ memiliki persepsi negatif. Persepsi efek samping yang positif berarti efek samping tidak menjadi hambatan pasien dalam mengonsumsi OAD.

Persepsi efek samping dinilai dengan 4 butir pertanyaan yang tercantum pada tabel II. Seluruh butir pertanyaan dipersepsikan baik oleh lebih dari 50 persen dari responden. Terdapat 12 orang yang pernah merasakan efek samping pengobatan, namun hanya 4 yang menghentikan pengobatan karena hal tersebut. Hal itu sejalan dengan penelitian sebelumnya. ${ }^{11}$ Pertanyaan yang paling banyak dipersepsikan negatif adalah penggunaan OAD yang setiap hari akan berakibat buruk (jangka panjang). Kepercayaan pasien terhadap efek buruk yang dapat membahayakan bagi tubuh akan menurunkan kepatuhan pasien dalam mengonsumsi OAD.12,13,14 Perlu edukasi mengenai cara meminimalisir terjadinya efek samping maupun efek jangka panjang. Selain itu, perlu dilakukan pemantauan secara berkala terhadap kondisi pasien. ${ }^{2}$

Persepsi dorongan konsumsi obat memiliki nilai mean logit (M) sebesar 1,54 (Gambar 4). Berdasarkan nilai tersebut, terdapat 31 responden $(67,4 \%)$ memiliki persepsi positif dan 15 responden (32,6\%) memiliki persepsi negatif. Persepsi dorongan konsumsi positif berarti pasien memiliki dorongan untuk mengonsumsi OAD yang tinggi dan hambatan yang rendah.

Persepsi dorongan konsumsi dinilai menggunakan 6 poin pertanyaan yang 
Tabel II. Distribusi Jawaban Responden

\begin{tabular}{|c|c|c|}
\hline \multirow{2}{*}{ Pertanyaan } & \multicolumn{2}{|c|}{ Jawaban $(\mathrm{N}=46)$} \\
\hline & Ya & Tidak \\
\hline \multicolumn{3}{|l|}{ Persepsi Manfaat Pengobatan } \\
\hline $\begin{array}{l}\text { Mengurangi atau menghilangkan gejala dan keluhan } \\
\text { diabetes saya }\end{array}$ & $31(67,4 \%)^{*}$ & $15(32,6 \%)$ \\
\hline Menurunkan kadar glukosa darah saya & $42(91,3 \%)^{*}$ & $4(8,7 \%)$ \\
\hline Membuat saya menjadi merasa sehat dan bugar & $34(73,9 \%)^{*}$ & $12(26,1 \%)$ \\
\hline $\begin{array}{l}\text { Mencegah terjadinya perburukan atau komplikasi pada } \\
\text { tubuh saya }\end{array}$ & $34(73,9 \%)^{*}$ & $12(26,1 \%)$ \\
\hline \multicolumn{3}{|l|}{ Persepsi Tata Cara Konsumsi Obat } \\
\hline Saya perlu meminum OAD secara rutin setiap hari & $40(87 \%)^{*}$ & $6(13 \%)$ \\
\hline Saya dapat meminum OAD kapan saja, sesuai kemauan saya & $9(19,6 \%)$ & $37(80,4 \%)^{*}$ \\
\hline $\begin{array}{l}\text { Saya dapat menambah dosis OAD jika saya merasa } \\
\text { membutuhkanya }\end{array}$ & $3(6,5 \%)$ & $43(93,5 \%)^{*}$ \\
\hline $\begin{array}{l}\text { Saya dapat mengurangi atau memberhentikan konsumsi } \\
\text { OAD jika sudah merasa lebih baik }\end{array}$ & $12(26,1 \%)$ & $34(73,9 \%)^{*}$ \\
\hline $\begin{array}{l}\text { Saya dapat mengurangi atau memberhentikan konsumsi } \\
\text { OAD jika tidak merasakan perbaikan }\end{array}$ & $2(4,3 \%)$ & $44(95,7 \%)^{*}$ \\
\hline Saya hanya meminum OAD jika merasa perlu saja & $7(15,2 \%)$ & $39(84,8 \%)^{*}$ \\
\hline $\begin{array}{l}\text { Konsumsi OAD yang tidak teratur akan membuat hasil yang } \\
\text { kurang maksimal }\end{array}$ & $41(89,1 \%)^{*}$ & $5(10,9 \%)$ \\
\hline \multicolumn{3}{|l|}{ Persepsi Efek Samping Pengobatan } \\
\hline $\begin{array}{l}\text { Saya pernah mengalami dan merasakan efek samping yang } \\
\text { ditimbukan oleh pengobatan diabetes saya }\end{array}$ & $12(26,1 \%)$ & $34(73,9 \%)^{*}$ \\
\hline $\begin{array}{l}\text { Saya pernah menghentikan penggunaan obat karena } \\
\text { merasakan efek samping }\end{array}$ & $4(8,7 \%)$ & $42(91,3 \%)^{*}$ \\
\hline $\begin{array}{l}\text { Konsumsi OAD setiap hari akan membuat hal yang buruk } \\
\text { bagi tubuh saya }\end{array}$ & $22(47,8 \%)$ & $24(52,2 \%)^{*}$ \\
\hline $\begin{array}{l}\text { Saya merasa ragu untuk mengonsumsi obat karena takut } \\
\text { terjadi efek samping }\end{array}$ & $5(10,9 \%)$ & $41(89,1 \%)^{*}$ \\
\hline \multicolumn{3}{|l|}{ Persepsi Dorongan Konsumsi Obat } \\
\hline $\begin{array}{l}\text { Saya merasa nyaman dengan penggunaan OAD yang } \\
\text { diperintahkan dokter }\end{array}$ & $40(87 \%)^{*}$ & $6(13 \%)$ \\
\hline Menurut Saya OAD mudah untuk didapatkan & $45(97,8 \%)^{*}$ & $1(2,2 \%)$ \\
\hline Tata cara konsumsi OAD mudah untuk dimengerti & $43(93,5 \%)^{*}$ & $3(6,5 \%)$ \\
\hline Saya akan mengonsumsi OAD secara rutin dan teratur & $39(84,8 \%)^{*}$ & $7(15,2 \%)$ \\
\hline Saya merasa bosan dalam mengonsumsi OAD setiap hari & $27(58,7 \%)$ & $19(41,3 \%)^{*}$ \\
\hline Saya merasa OAD membebani saya secara ekonomi & $9(19,6 \%)$ & $37(80,4 \%)^{*}$ \\
\hline
\end{tabular}

* = jawaban yang berorientasi positif

tecantum pada tabel II. Sebanyak 87\% responden menyatakan nyaman dengan terapi yang dijalani dan 93,5\% menyatakan bahwa tata cara penggunaan mudah untuk dipahami. Hampir seluruh responden $(97,8 \%)$ menyatakan bahwa OAD mudah didapatkan.
Sebanyak 80,4\% responden menyatakan bahwa OAD tidak membebani secara ekonomi. Beberapa hal tersebut dapat menjadi faktor yang mendukung konsumsi OAD. ${ }^{6}$ Terdapat satu pertanyaan yang dipersepsikan negatif oleh lebih dari 50\% responden, yaitu 
Persepsi Pasien DM Tipe 2 Terhadap Penggunaan Obat Antidiabetes Oral

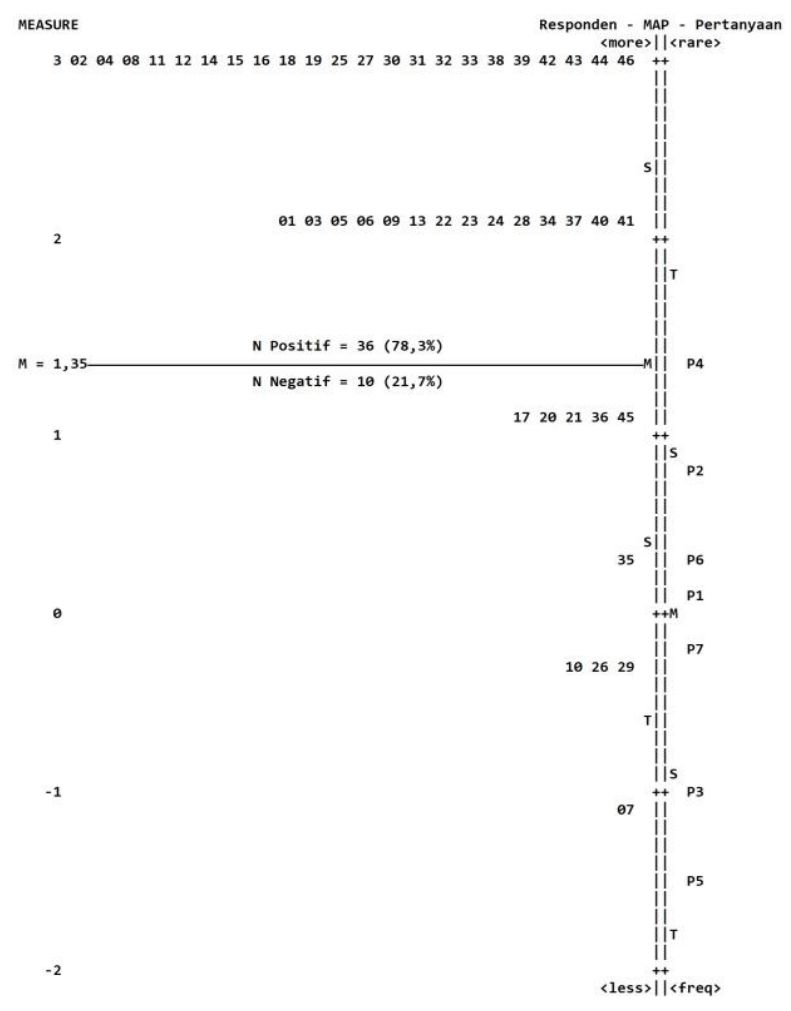

Gambar 2. Wright Map Distribusi Responden dan Item Pertanyaan Persepsi Tata Cara Konsumsi Obat

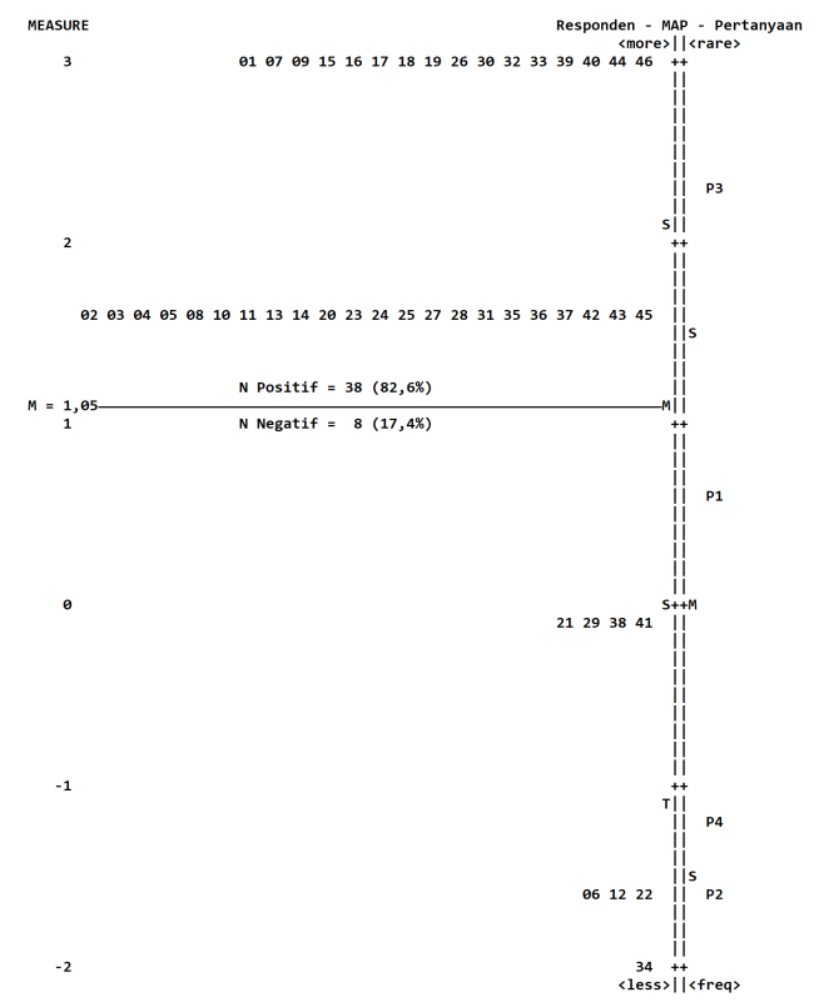

Gambar 3. Wright Map Distribusi Responden dan Item Pertanyaan Persepsi Efek Samping Pengobatan 
Eko Kuncoro Manunggaling Gusti, et al

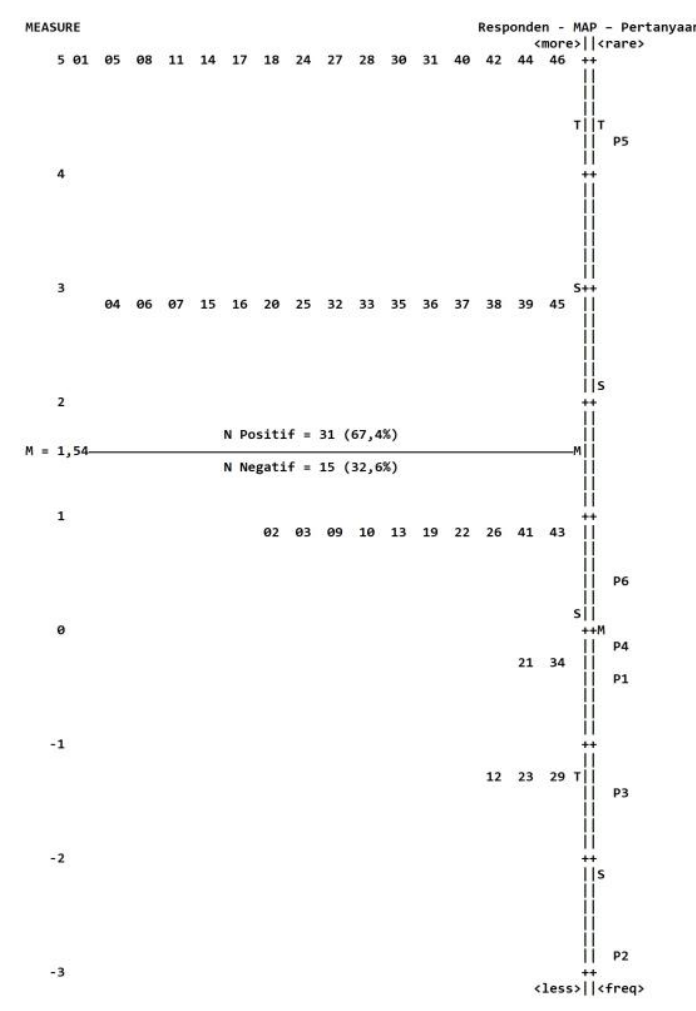

\section{Gambar 4 Wright Map Distribusi Responden dan Item Pertanyaan Persepsi Dorongan Konsumsi Obat}

kebosanan dalam mengonsumsi OAD. Hal ini dapat terjadi karena pengobatan DMT2 yang dilakukan terus menerus seumur hidup rawan terhadap rasa bosan. ${ }^{2}$ Tetapi, $84,8 \%$ responden menyatakan bahwa mereka akan terus mengonsumsi OAD secara rutin kedepannya yang merupakan semangat positif dalam konsumsi obat. Beberapa hal diatas menunjukkan bahwa pengambilan keputusan sangat dipengaruhi oleh keseimbangan berbagai aspek persepsi. ${ }^{8,11}$

Secara keseluruhan, pasien DMT2 terhadap penggunaan OAD di RSHS mayoritas memiliki persepsi positif. Hal ini dapat disebabkan oleh lokasi penelitian yang merupakan rumah sakit rujukan tingkat 3, sehingga pasien sudah lama mengalami DMT2 atau memiliki komorbid tertentu. Selain itu, kemungkinan pasien memiliki kesadaran yang cukup tinggi mengenai pengobatan, dilihat dari upaya yang dilakukan secara berjenjang dari FKTP hingga ke FKRTL tingkat 3. Keterbatasan penelitian ini adalah belum dapat menggambarkan secara penuh persepsi pasien DMT2 dalam skala yang luas karena hanya dilakukan di satu tempat. Selain itu, mayoritas pasien DMT2 di RSHS mendapatkan terapi insulin dan sangat sedikit yang mendapatkan terapi OAD.

Perlu dilakukan penelitian serupa kepada pasien di fasilitas kesehatan tingkat pertama dan kedua untuk mendapatkan gambaran yang menyeluruh. Dapat juga dilakukan penelitian mengenai hubungan persepsi dengan tingkat kepatuhan konsumsi obat, status kontrol DMT2 pasien, ataupun kualitas hidup pasien DMT2. Penelitian tersebut masih sangat jarang dilakukan di Indonesia.

\section{KESIMPULAN}

Persepsi pasien diabetes melitus tipe 2 terhadap penggunaan obat antidiabetes oral di 
RSUP Dr. Hasan Sadikin Bandung mayoritas positif pada empat aspek persepsi, yaitu manfaat pengobatan, tata cara penggunaan obat, efek samping pengobatan, dan dorongan konsumsi obat. Hal tersebut merupakan landasan yang baik bagi pasien untuk melakukan terapi secara teratur dan berkelanjutan. Pada aspek dorongan konsumsi, terdapat satu masalah mengenai kebosanan yang dipersepsikan negatif oleh lebih dari setengah responden. Perlu upaya yang holistik dan terus menerus dari tenaga medis untuk membentuk dan menjaga persepsi positif dari pasien DMT2 terhadap pengobatan yang sedang dijalani.

\section{DAFTAR PUSTAKA}

1. Global Report on Diabetes. Geneva: World Health Organization; 2016. http://www.who.int/iris/handle/10665/ 204871.

2. Masharani U, German MS. Pancreatic Hormones and Diabetes Mellitus. In: Gardner DG, Shoback D, eds. Greenspan's Basic \& Clinical Endocrinology. 10th ed. San Fransisco: McGraw-Hill Education; 2018:595-682.

3. International Diabetes Federation. IDF Diabetes Atlas. 8th ed. Brussels: International Diabetes Federation; 2017. http://www.diabetesatlas.org.

4. American Diabetes Association. Classification and Diagnosis of Diabetes: Standars of Medical Care in Diabetes - 2018. Diabetes Care. 2018;41(January):513-527. doi:https://doi.org/10.2337/dc18-S002

5. Badan Penelitian dan Pengembangan Kesehatan. HASIL UTAMA RISKESDAS 2018. Jakarta; 2018. http://www.kesmas.kemkes.go.id/asset s/upload/dir_519d41d8cd98f00/files/Ha sil-riskesdas-2018_1274.pdf.

6. Polonsky WH, Henry RR. Poor medication adherence in type 2 diabetes: recognizing the scope of the problem and its key contributors. Patient Prefer Adherence. 2016;10:12991307.

7. Psarou A, Cooper H, Wilding JPH. Patients' Perspectives of Oral and Injectable Type 2 Diabetes Medicines, Their Body Weight and MedicineTaking Behavior in the UK: A Systematic Review and MetaEthnography. Diabetes Ther. 2018;9(5):1791-1810.

8. Myers DG. Sensation and Perception. In: Psychology. 9th ed. New York: Worth Publisher; 2010:229-290.

9. Shakibazadeh E, Larijani B, Shojaeezadeh D, Rashidian A, Forouzanfar M, Bartholomew L. Patients ' Perspectives on Factors that Influence Diabetes Self-Care. Iran J Publ Heal. 2011;40(4):146-158.

10. Guénette L, Lauzier S, Guillaumie L, Giguère G, Grégoire J-P, Moisan J. Patients ' beliefs about adherence to oral antidiabetic treatment: a qualitative study. Patient Prefer Adherence. 2015;9:413-420.

11. Al-qazaz HK, Hassali MA, Shafie AA, Sulaiman SAS, Sundram S. Perception and knowledge of patients with type 2 diabetes in Malaysia about their disease and medication: A qualitative study. Res Soc Adm Pharm. 2011;7(2):180-191.

12. Sweileh WM, Zyoud SH, Abu RJ, et al., Influence of patients' disease knowledge and beliefs about medicines on medication adherence: findings from a cross-sectional survey among patients with type 2 diabetes mellitus in Palestine. BMC Public Health. 2014;14(94). doi:10.1186/1471-2458-1494

13. Mann DM, Ponieman D, Leventhal H, Halm EA. Predictors of adherence to diabetes medications: the role of disease and medication beliefs. J Behav Med. 2009;32:278-284. 
Eko Kuncoro Manunggaling Gusti, et al

14. Aflakseir A. Role of illness and medication perceptions on adherence to medication in a group of Iranian patients with type 2 diabetes. J Diabetes. 2012;4:243-247. 